\title{
THE IMPACT OF THE UNCONDITIONAL CASH TRANSFER PROGRAM (BLT) ON CIGARETTE CONSUMPTION IN INDONESIAN SOCIETY
}

\author{
Inayati Nuraini Dwiputri \\ Faculty of Economics and Business, Universitas Gadjah Mada \\ (inayatinadp@gmail.com)
}

\begin{abstract}
One of the purposes of the unconditional cash transfer program (Bantuan Langsung Tunai/BLT) was to help the poor and near-poor households to fulfill their basic needs. This study attempted to identify the impact of the BLT on cigarette consumption in society; as it is well known that smoking has more disadvantages than benefits. The study used data from the Indonesian Family Life Survey (IFLS) 2000 and 2007 to capture the impact of the BLT on the cigarette consumption of households. By controlling for the characteristics of the respondents, and using the fixed effect at household and village level as an estimation technique, the empirical results showed that in general there was a changing pattern of cigarette consumption in Indonesian society, to which the BLT program has contributed. By influencing the savings of households, the BLT program has significantly decreased cigarette consumption in Indonesia. It could be explained by the permanent income hypothesis, where the BLT transfer can be categorized as a transitory income in that hypothesis. This study can be an input and consideration for the transfer policy's implementation in Indonesia in particular.
\end{abstract}

Keywords: Permanent income hypothesis, transitory income, cigarettes, Bantuan Langsung Tunai (BLT)

JEL Classification: H31, H53, I3, I18

\section{INTRODUCTION}

Since $2003^{1}$, Indonesia had become a net importer of oil, thus the rise of global crude oil prices could increase the price of fuel in Indonesia. The rise in fuel prices would increase the budget of the Government of Indonesia (GoI) for its fuel subsidies. Therefore, the GoI issued a policy to reduce fuel subsidies. Consequently, the price of fuel rose significantly in March $2005^{2}$. The rise in fuel prices led to a decrease in the purchasing power of society. Therefore, to compensate for it, the government implemented

\footnotetext{
${ }^{1}$ Indonesia withdrew from OPEC membership in 2008 because Indonesia was no longer meeting the criteria of an OPEC member. Being a net importer of oil, the rising oil price was unprofitable for Indonesia.

2 The increase in the price of fuel in March 2005 was from $\mathrm{Rp} 1,810$ to Rp2,400perliter. The policy of rising the fuel price significantly was to reduce the budget allocation for fuel subsidies, and was madeby President Susilo Bambang Yudhoyono, exactly five months after he became President. The previous president Megawati did not take the option of increasing the fuel price (suaramerdeka.com, 2014).
}

a program of unconditional cash transfers, namely, the Bantuan Langsung Tunai/BLT (Abidin, 2012) ${ }^{3}$.

This unconditional cash transfer was aimed at helping the poor to meet their basic needs, to prevent a decline in their welfare due to economic distress, and to increase the common social responsibility. Meanwhile, the targets of the BLT program were poor and near-poor households in all the regions of Indonesia. In general, the goal of the BLT was to maintain and/or improve the welfare of communities, in particular through their food consumption. The transfer program was considered to be able to reduce poverty and also prevent the transmission of intergenerational poverty (Rawlings \& Rubio, 2005).

The implementation of the BLT program in Indonesia has attracted attention from some

\footnotetext{
${ }^{3}$ Unconditional cash transfer $(B L T)$ can be defined as government assistance in the form of cash given to poor households in compensation for the rise in fuel prices.
} 
studies. Rasyid (2013) studied the effects of the BLT on private transfers to other households that are considered to be economically disadvantaged. Similarly, Cox (2004) and Park (2003) have stated that private transfers are responsible for the income of poor households. This was supported by Sharma and Lal (2009), who found that private transfers could decrease poverty in India. Another study of the BLT in Indonesia was by Cameron and Shah (2012), which showed that there were instances of mistargeting of the BLT program. Transfers of BLT cash are significantly associated with an increase in crime and a decline in the social capital.

To enrich the study of the BLT program's impact, this study aimed to determine the effects of the BLT on cigarette consumption at the household level. As far as the author's knowledge is concerned, it has not been identified in any previous study. In addition, this study also uses the permanent income hypothesis theory approach in explaining changes in the cigarette consumption of the community, especially the BLT recipient households. The study aimed to identify whether the BLT program changed the consumption behavior, especially of cigarettes, at the household level. Although cigarettes are known for having negative effects on health, they also provide a high excise income for the $\mathrm{GoI}^{4}$. Nevertheless, starting in 2015, the government has given priority to the public health aspects, rather than the increase in state revenue from tobacco excise (NKAPBN 2014) 5

It is known that the determinants of cigarette consumption are the price of cigarettes (Andrews \& Franke, 1991; Gallus et al., 2006), advertising and income (Andrews \& Franke, 1991). Therefore, this study tries to identify the impact of the BLT funding on cigarette consumption, as the BLT can increase the income of its poor recipients in particular. This study identifies whether this increased income can influence a rise in the consumption of cigarettes, as Andrews and Franke (1991) have stated. This study also tries to prove there has been a decline in the expenditure on cigarettes

\footnotetext{
${ }^{4}$ For more detail see NKAPBN 2014. In 2013, tobacco excise was $96.2 \%$ of total excises.

5 It was stated in NKAPBN 2014
}

by Indonesian households because of the BLT program. By using the fixed effect at the village level as an estimation technique, the analysis showed that the BLT has a significant effect on the change in households' cigarette consumption $^{6}$. The argument was that the recipients of the BLT used the funds for investments, so the purchasing power of society was still low or maybe even lower than before. Because of their investments, they decreased their consumption of cigarettes (because they are not a primary need). On average, the BLT program did decrease the expenditure on cigarettes.

\section{LITERATURE REVIEW}

In allocating their resources, households can use their existing resources on both sides i.e. consumption and investment. Romer (2012: 365379) explained that there are two relevant consumption theories up to the present time. They are the permanent income hypothesis (consumption under certainty) and the random walk hypothesis (consumption under uncertainty). The permanent income hypothesis is a hypothesis illustrating that individual consumption is influenced by received income, in which the income is certain. Meanwhile, the random walk hypothesis is a hypothesis illustrating that individual consumption is influenced by an individual's expectations of his/her future income.

This study discusses the impact of the BLT program on the cigarette consumption of the recipient households. In the implementation of the BLT program, the village head socialized the disbursement period and the amount of funds to be received to the recipients of the BLT. Thus, the BLT fund can be categorized for those of a certain income, while the amount and the disbursement period of the funds are known by the recipient. Therefore, the appropriate consumption theory approach in this case is the permanent income hypothesis. In addition to having a permanent income, the households also have a transitory income. The transitory income is the difference between their current income

\footnotetext{
${ }^{6}$ This paper considers that the variations of traditions in villages are the factors that influence the consumption expenditure.
} 
and their permanent income (Romer, 2012:367). Wages per month can be categorized as a permanent income. Therefore, the BLT fund is categorized as transitory income.

\section{The Theory of Consumption: Permanent Income Hypothesis}

Romer (2012: 366) illustrated the consumption behavior from the utility function of an individual. It was assumed that an individual living at period $\mathrm{T}$ has a lifetime utility as follows:

$$
U=\sum_{t=1}^{T} U\left(C_{t}\right)
$$

And the budget constraint is:

$$
\sum_{t=1}^{T} C_{t} \leq A_{0}+\sum_{t=1}^{T} Y_{t}
$$

When the individual maximizes their utility, the Lagrangian function becomes:

$$
\begin{aligned}
L= & \sum_{t=1}^{T} U\left(C_{t}\right)+\lambda\left(A_{0}+\sum_{t=1}^{T} Y_{t}-\right. \\
& \left.\sum_{t=1}^{T} C_{t}\right)
\end{aligned}
$$

If $\frac{\partial L}{\partial C_{t}}=0$, so the marginal utility of consumption is equal to $\lambda$. It happens in each period, meaning that the marginal utility of consumption is constant. It concludes that $C_{1}=C_{2}=\cdots=C_{t}$. Then substitution to Equation (2) becomes:

$$
\begin{gathered}
T C_{t}=A_{0}+\sum_{t=1}^{T} Y_{t} \\
C_{t}=\frac{1}{T}\left[A_{0}+\sum_{t=1}^{T} Y_{t}\right]
\end{gathered}
$$

The equation above means that the consumption of an individual in each period does share the lifetime resources for each period of his/her life. Equation (4) shows that the consumption of an individual in each period is not only determined by their income in that period, but also by all their income or wealth during their entire life. Friedman (1957) said that consumption is determined by permanent income. This is acknowledged as the permanent income hypothesis. In the simple model, the income of an individual is shared between two activities, consumption and savings. Thus, the savings of an individual are:

$$
S_{t}=Y_{t}-C_{t}=Y_{t}-\frac{1}{T}\left[A_{0}+\sum_{t=1}^{T} Y_{t}\right]
$$

According to the sources of the funds, the income of an individual can be categorized as a permanent income and a transitory income. Equation (5) said that the savings of an individual would increase if their permanent income rises relative to the average income. Equation (5) also concluded that the savings of an individual would increase if their transitory income rises. Related to this study, the BLT transfer can be categorized as a transitory income. Therefore, the BLT payments will increase the savings of the recipients. This study assumed that household savings equal household investments $(\mathrm{I}=\mathrm{S})$.

\section{Transfer Program}

The unconditional cash transfer (BLT) program was a government policy for maintaining the level of consumption of poor and near-poor households, due to the reduction in the fuel subsidy that significantly increased the price of fuel. The increase in the price of fuel had decreased the purchasing power of poor households and their ability to meet their basic necessities. Therefore, the GoI issued the BLT program to help the poor to be able to meet their basic needs and prevent a decline in their level of welfare.

The targeting of the BLT program was tailored to the data collected by the Central Statistics Agency (Badan Pusat Statistik/BPS), which includes the poor and near-poor households in all regions of Indonesia. The targeted households fall into the category of very poor, poor, and near-poor, in accordance with the results of the BPS's data. The BPS used 14 indicators in determining the recipients of the BLT program. The recipients of the BLT had to meet at least 9 of the 14 indicators defined by the BPS $^{7}$.

\footnotetext{
1) The floor area of the residence is less than 8 square meters per person; 2) The floor of the residence is made of soil, bamboo, or cheap wood; 3) The walls of the residence are made of bamboo, thatch, low-quality wood, or the walls are without plaster; 4) The residence does not have a toilet or WC facilities; 5) The residence does not use electricity for lighting but use other means, such as oil lamps or torches; 6) Source of drinking water from wells or unprotected springs, rivers, or rainwater; 7) The fuel for daily cooking is firewood, charcoal, or
} 
Hossain et al. (2012), through their qualitative analysis concluded that the BLT has helped society to smooth its consumption. Cameron and Shah (2012) found that mistargeting by the cash transfer program in Indonesia was significantly associated with an increase in crime and a decline in the social capital, due to the inappropriateness of the BLT program's administration ${ }^{8}$. Cameron and Shah (2012) used the Susenas and Podes data, which area random sample of 277,202 households. However, Cameron and Shah (2012) could not capture the changes in the probability of a household being a victim of crime very well, because the observations of the sample were not longitudinal data. Therefore, this study attempted to use longitudinal data in order to capture the changes in household consumption from year to year.

Rasyid $(2013)^{9}$ also found a negative impact of the BLT, i.e. the reduction of private transfers. This was related to the habit of Indonesians who like to help their poor neighbors or close relatives. Thus, due to the existence of the BLT program, they reduced their transfers to poor relatives and neighbors. The rich felt that the poor did not need their assistance anymore because of the transfer from the GoI to the poor and near-poor.

In addition to the BLT, another policy existed for a transfer program in Indonesia, which was known as the Inpres Desa Tertinggal (IDT) transfer program. That program influenced the increase of man-child working

kerosene; 8) Eat meat, milk, or chicken no more than once a week; 9) Buy a pair of new clothes only once a year; 10) Only eat one or two times a day; 11) Notable to pay for the cost of treatment in health centers like puskesmas or polyclinics; 12) Source of income of household heads is from farming with a land area of $0.5 \mathrm{acres}$, or as a farm laborer, fishermen, construction worker, plantation worker, or other jobs with an income of less than Rp600,000 per year; 13) Educational attainment of household head is no schooling, or not completed primary school (SD), or only completed SD; 14) Do not have savings or salable goods with a value of at least Rp500,000.

8 Cameron and Shah (2012) used the data of the National Socioeconomic Survey (SUSENAS) 2006 and the data from the Village Potential (Podes) that were collected in April 2005(before the BLT conducted).

9 Rasyid (2013) used a Propensity Score Matching (PSM) method in the model of estimation hours (Yamauchi, 2005). Other research into the impact of transfer programs to communities includes that by Soares et al. (2010), which found that conditional transfers in Latin America had been able to reduce inequality, poverty, and have a positive impact on education, without any negative impact on the labor force's participation. Soares et al. (2010) also revealed that the conditional cash transfers in Latin America failed to have their intended impact on health and nutrition. Ressler $(2008)^{10}$ found that transfer programs could increase social participation, as the programs' funds can help communities to engage in community events. The programs funds were 'resources' to establish some events in the community. By knowing the previous studies, and the desire of the GoI to decrease the consumption of cigarettes in order to maintain public health, this study attempts to identify the effect of the BLT program on the consumption of cigarettes using longitudinal data and appropriate methodology

\section{METHODOLOGY}

\section{Data}

This study used the Indonesian Family Life Survey (IFLS) data collected by the RAND Corporation. The Indonesian Family Life Survey (IFLS) ${ }^{11}$ is a longitudinal survey of socioeconomic and health matters; the survey was conducted by collecting individuals, households and communities' data. The IFLS data includes information about social and economic facilities used by the public, such as health and education facilities. This study used panel data ${ }^{12}$ that

10 Ressler (2008) using qualitative methods for the study in Kenya

11 Witoelar et al. (2009) revealed that, the first wave, IFLS1, was conducted in 1993-1994. The sample survey represented about $83 \%$ of the Indonesian population, living in 13 of the 26 provinces, consisting of 7,224 households which were interviewed and individual-level data were collected from over 22,000 individuals. The second wave of the survey (IFLS2) with the same sample, was conducted in 1997, and then another survey (IFLS2+) was conducted in 1998. The third wave of the survey, IFLS3, with a full sample, was carried out in 2000. Furthermore, IFLS4 was conducted in late2007 through to early 2008, with the same respondents as IFLS1 in1993.

12 This study used the available household data on IFLS3 and IFLS 4by identifying the household's identity. 
consisted of data from 2000 (IFLS 3) and 2007 (IFLS 4) to capture the periods before and after the implementation of the BLT program. The outcome to be observed in this study was the change in the expenditure on cigarettes, as influenced by the BLT program. However, there were weaknesses in estimating the impact of the BLT program using IFLS 3 and 4 data because there was a long period when no fresh data were collected, between 2000 (IFLS 3) and 2005, when the BLT program was conducted. However, this study can capture the consumption by households after the BLT program was implemented, since this behavior is captured well by the IFLS 4 data.

\section{Model and Estimation Techniques}

Finding the counterfactual is the important thing in any impact analysis (Khandker et al., 2010), i.e. the conditions that would occur if the recipient of the BLT did not receive the program. However, in the analysis of the impact of the BLT program, it was not have counterfactual; this is because almost all the poor households meeting the criteria to obtain the BLT funding had received it, meaning that the program had been implemented. Thus, the Randomized Control Trial (RCT) method, usually the best method to analyze impact evaluations, cannot be applied to this impact analysis. Therefore, this study used the fixed effect method as the rigorous estimation technique.

The variable of the BLT program in the model would represent a dummy, in which the treatment group was households that received the BLT program's funding, as dummy 1. Meanwhile the control group was households that did not receive the BLT program, as dummy 0 . To avoid bias, some information that is considered to be important about the households would be included in the control variables. Nevertheless, the bias could still potentially arise if it was unobserved and a time invariant household characteristic, which can affect the outcomes. An example of an unobserved and time invariant household characteristic is the different preferences of each household. Because there was no data about the preference of each household, that variable would be include in the error term. So, it can cause bias at the household level because there will be a correlation between the error term and the variable of the program ${ }^{13}$.

Therefore, controlling for the possibility of time invariant unobserved factors at the household and individual level, in the participation of the program, was anticipated by the method of fixed effects at the household level, so that the bias problems can be overcome. Thus, by using the fixed effects method at the household level, according to Wooldridge (2003) the research model is as follows:

$$
Y_{i j t}=\alpha_{0}+\beta_{1} B L T_{i j t}+\beta_{2} X_{i j t}+\mu_{i}+v_{j t}
$$

$Y_{i j t}$ is the outcome variable that describes the cigarette consumption of household- $i$, village $-j$, and year-t. BLT is a dummy variable that is 1 for household $-i$ in village $-j$ which received the BLT program in year- $t$, while 0 for household $-i$ in village $-j$ who did not receive the BLT program in year $-t$. Variable $X_{i j}$ are the variables of the household characteristics, which is a control variable. $V_{j t}$ is an error term for households in village $-j$, year $-t$. $\mu_{i}$ is the fixed effect at the household level. Furthermore, the error term is assumed to be uncorrelated with the variable $B L T$, once controlled by the household's fixed effect. Some of the control variables, such as the socio-economic demographic factors that can influence the consumption of households (Eshghi \& Lesch, 1993) were included as control variables. Miles (1997) also stated that control variables that can influence the consumption of households are the size of the household, the sex of the head of the household, and the number of years of schooling the household head received. Those variables were also included in the model.

Another bias that arose was that the provision of the program was not random, the BLT was given to poor households which met

\footnotetext{
13 There was a relationship between the program variable and the preference of each household. However, the preference between households who receive the program and those that do not receive the program was different. It can cause bias in the estimation of the impact evaluation of the program because there was a correlation between the error term and the program variable.
} 
the criteria for poor households established by the Badan Pusat Statistik/BPS (Isdijoso, 2016; Medan, 2010). Thus, there would be a potential bias due to the non-random program placement ${ }^{14}$ that may influence the outcome. This bias also happened at the household level because the BLT was given directly to poor households by their village heads. Misallocation of the program, caused by unobserved factors such as errors in reporting the condition of households to the head of the village would also lead to bias at the household level. This means that some relatively rich households probably also benefitted from the program. This bias because of the error reporting is overcome by the fixed effect at the household level.

There is a probability of potential bias that arises due to unobserved and time invariant village characteristics that can affect the outcome, such as the different traditions of the villages ${ }^{15}$. Therefore, Equation (6) may be less representative. To overcome potential bias at the village level, fixed effects could be used at the level of the enumeration areas (like the village level) ${ }^{16}$-which may be stated as the village fixed effect- to estimate the effect of the BLT on the cigarette consumption and expenditure of society. By using fixed effects at the village level, then Equation (6) becomes:

$$
Y_{i j t}=\alpha_{0}+\beta_{1} B L T_{i j t}+\beta_{2} X_{i j t}+\mu_{j}+v_{i t}
$$

$\mu_{j}$ is a fixed effect at the village level. Further, the error term is assumed to be uncorrelated with the variable of the program, once controlled by the village fixed effect.

The fixed effect estimator has eliminated the constant characteristics of community from time-1 to time-2 (Gertler \& Molyneaux, 1994;

\footnotetext{
14 BLT was not given randomly to poor households. But there were some criteria of poor household that would receive the BLT. Almost all the poor households that met the criteria for receiving the BLT received it in 2005.

15 Some traditions in Indonesian villages include gatherings of the community. The difference is the level of frequency. It can be very often or very rarely. According to interviews with some smokers, gatherings with other smokers can influence the increase of consumption of cigarette.

16 There are 321enumeration areas in the study.
}

Heckman \& Robb, 1985; Pitt et al., 1999; Yamauchi, 2001). The fixed effects approach was to add a dummy variable for each village in the analysis. With the village fixed effects estimation technique, the unobserved and time invariant characteristic at the village level cannot lead to bias in estimating the coefficients of the covariates (Wooldridge, 2003) as represented in Equation (7).

\section{RESULTS AND DISCUSSION}

Tabulated IFLS 4 data showed that there were 2,360 sample households that received the BLT and the rest of the sample, 6,354 households, did not receive it. The data showed that, in the last year, some households received BLT funding to the value of a minimum amount of Rp90,000 and a maximum of $\mathrm{Rp} 1,800,000$; while the average received by each household last year was around $\mathrm{Rp} 777,500$. It means that there were irregularities in the implementation of the BLT program, the data shows there were some households that only received Rp90,000; although the government had set the BLT funding given to the poor households at Rp100,000 per month.

The average received last year by the households in receipt of BLT funding was Rp777,500 and the standard deviation is Rp813,845. The large standard deviation means that there were some households that received much more than the average. That amount was quite enough for a poor household to make an investment or buy an asset.

Descriptively, there was an increase in the households' cigarette consumption from 2000 to 2007 of $1.88 \%$ for all samples. Furthermore, the standard deviation of cigarette consumption in 2000 was much lower than in 2007. The increasing expenditure on cigarettes may have a negative impact on health. Therefore, the BLT program needs to be examined rigorously if the increase in cigarette consumption is influenced by the BLT program. The estimation of the impact of the BLT program on cigarette consumption is shown in Table 2. 
Table 1. The Description of All Samples (Panel Data)

\begin{tabular}{|c|c|c|c|c|}
\hline \multirow{2}{*}{ Variable } & \multicolumn{2}{|c|}{ Year 2000} & \multicolumn{2}{|c|}{ Year 2007} \\
\hline & Mean & St. dev & Mean & St. dev \\
\hline Age of household head & 45.70 & 14.76 & 49.24 & 13.99 \\
\hline Number of household members & 4.31 & 1.97 & 4.04 & 1.87 \\
\hline Number of males in household & 1.44 & 0.93 & 1.38 & 0.90 \\
\hline Number of children in household & 1.31 & 1.23 & 1.16 & 1.14 \\
\hline Education of household head & 6.46 & 4.64 & 6.93 & 4.79 \\
\hline $\begin{array}{l}\text { Consumption of Cigarettes }(\mathrm{Rp}) \\
(\text { Base }=2000)\end{array}$ & 40,408 & 72,958 & 46,061 & 114,895 \\
\hline BLT fund received last year $(\mathrm{Rp})$ & - & - & 777,500 & 813,845 \\
\hline Total BLT fund received (Rp) & - & - & 928,875 & 843,205 \\
\hline
\end{tabular}

Source: Author's calculation, 2016

Table 2. Impact of BLT Program on Household Cigarette Consumption ${ }^{17}$

\begin{tabular}{|c|c|c|c|c|}
\hline \multirow[t]{2}{*}{ Variable } & \multicolumn{2}{|c|}{ Fixed Effect (1) } & \multicolumn{2}{|c|}{ Fixed Effect (2) } \\
\hline & Model 1 & Model 2 & Model 3 & Model 4 \\
\hline BLT & 0.03 & 0.00 & $-0.09 * * *$ & $-0.25 *$ \\
\hline Amount of BLT fund (Rp);Ln_BLTRp & & -0.01 & & -0.00 \\
\hline Smoker status $(\text { smoker }=1)^{18}$ & $10.50 * * *$ & $10.60 * * *$ & $10.66 * * *$ & $10.69 * * *$ \\
\hline Age of household head (years) & $-0.00 * *$ & $-0.00 *$ & $-0.00 * * *$ & $-0.00 * * *$ \\
\hline Sex of household head $(\operatorname{man}=1)$ & $-0.11 * * *$ & -0.03 & $-0.15 * * *$ & $-0.12 * * *$ \\
\hline Schooling of household head (years) & $0.01 * *$ & 0.00 & $0.02^{* * * *}$ & $0.02^{* * *}$ \\
\hline Number of household members & 0.02 & 0.00 & $0.02 * * *$ & $0.03^{* * * *}$ \\
\hline Number of males in household & $0.12 * * *$ & $0.11 * * *$ & $0.11^{* * *}$ & $0.10^{* * *}$ \\
\hline Number of children in household & -0.01 & 0.01 & $-0.02 *$ & $-0.02 *$ \\
\hline \multicolumn{5}{|l|}{ Characteristic of Residence } \\
\hline Live in rural area (yes $=1)$ & $-0.06^{*}$ & $-0.08 * *$ & $-0.08 * * *$ & $-0.08 * * *$ \\
\hline Distance to sub-district capital & -0.00 & -0.00 & $-0.00 * *$ & $-0.00^{* *}$ \\
\hline Distance to district capital & -0.00 & -0.00 & 0.00 & 0.00 \\
\hline Distance to market & $0.01 * * *$ & $0.01 * *$ & $0.01 * *$ & 0.01 \\
\hline Availability of electricity (yes $=1$ ) & $0.18 * *$ & $0.30 * * *$ & $0.15^{*}$ & $0.18 * *$ \\
\hline Availability of water pump (yes $=1$ ) & -0.04 & -0.01 & 0.01 & 0.03 \\
\hline Availability of market (yes =1) & -0.04 & $-0.04 *$ & -0.02 & -0.02 \\
\hline Availability of station (yes $=1$ ) & 0.00 & -0.01 & 0.00 & 0.01 \\
\hline Kind of road (paved road, asphalt $=1$ ) & 0.04 & -0.00 & 0.05 & 0.03 \\
\hline Availability of finance institution (yes $=1$ ) & -0.02 & -0.02 & -0.00 & 0.01 \\
\hline & \multicolumn{3}{|c|}{ Intercept } & $-0,245 * *$ \\
\hline $\mathrm{R}^{2}$ & 97.78 & 97.84 & 97.84 & 97.91 \\
\hline $\mathrm{N}$ & 17,426 & 15,331 & 17,426 & 15,331 \\
\hline
\end{tabular}

Source: author's calculation, 2016

Fixed Effect (1): fixed effect at household level

Fixed Effect (2): fixed effect at village level

$* * *$ : significant at $\alpha=1 \%$; **: significant at $\alpha=5 \%$; *: significant at $\alpha=10 \%$

\footnotetext{
${ }^{17}$ Ln real consumption, base: 2000. The real value was calculated based on the GDP deflator from the statistics of the World Bank's website. The variable of cigarette consumption and total amount of BLT fund were transformed to a log natural (Ln).

${ }^{18}$ Smoker status means that there was at least one smoker in the household
} 
The analysis of the consumption of cigarettes was controlled by the smoker's status variable. Models (1) and (2) used the fixed effect at the household level, showed that the BLT program positively but not significantly affected the households' consumption of cigarettes. Models (3) and (4) used the fixed effect at the household level, showed that the BLT program negatively and significantly affected the households' consumption of cigarettes. The estimation of the fixed effect method at the village level is better than the fixed effect at the household level. This can be seen from the larger of the $\mathrm{R}^{2}$ adjusted results in the model. It can be concluded that the BLT had a significant negative effect on the cigarette consumption of households.

The result indicates that the BLT funds were not used for consumption at all; it is possible the households used them for an investment, as the permanent income hypothesis has shown. Funds from the BLT program, as a transitory income for the household can raise the investments of the household. This is because the allocated BLT fund was Rp100,000 per month, and was not given on a monthly basis, but every three months or more. This would be a sufficient amount for poor households to save, invest or to buy assets. This also fits with Shefrin and Thaler (1988), who concluded that the marginal propensity to consume transitory income is lower than the marginal propensity to consume permanent income.

Another problem that arose was the households also benefitted from other programs, such as the Program Keluarga Harapan (PKH) or raskin. To identify this in more depth, the study included the dummy variable for households who receive assistance from other programs. The study added the variables PKH and raskin, where the dummy was 1 (one) and represented the households who received the PKH program, and the dummy was 0 (zero) who those who did not. As well as the PKH variable, the dummy for the raskin variable also consists of a dummy of either 0 or 1 . Dummy 1 (one) represented a household who received the raskin program, and dummy 0 (zero) for those who did not. This analysis is presented in Table 3 as follows.

After the study controlled for the PKH and raskin program variables, Table 3 shows that the PKH program or raskin program did not significantly influence the consumption of cigarettes by BLT recipient households particularly. We found that there was a significant association between the BLT and raskin variable. It showed that there were 2,010 households who received the BLT and also benefited from the raskin program. The households that did not get the BLT program, did not receive the raskin program either. Therefore there was a significant association between the recipients of raskin and the BLT program by the $\mathrm{p}$-value $=0.000$.

The existence of a smoker in a household has a significant effect on the cigarette consumption of the household. The age of the household's head also affects the cigarette consumption in the household. The older the household head is, the lower the cigarette consumption is in the household. Households with male heads have a lower cigarette consumption than female-headed households. Households that have a large number of adult household members have a higher cigarette consumption. Households that have more males also have a higher cigarette consumption. Household that have more children have a lower cigarette consumption. The households in rural areas have a lower cigarette consumption (in rupiah) ${ }^{19}$. The households that are further away from their subdistrict capital have a lower consumption of cigarettes. The households that are further away from the market have a higher consumption of cigarettes.

\footnotetext{
19 The study did not identify the number of cigarettes they consume but the consumption of cigarettes (in rupiah).
} 
Table 3. Impact of BLT Program on Household Cigarette Consumption ${ }^{20}$

\begin{tabular}{|c|c|c|}
\hline \multirow{2}{*}{ Variable } & \multicolumn{2}{|c|}{ Fixed Effect (2) } \\
\hline & Model 5 & Model 6 \\
\hline BLT & $-0.073 * * *$ & $-0.245^{*}$ \\
\hline PKH & $-0,323$ & $-0,343$ \\
\hline Raskin & $-0,023$ & -0.013 \\
\hline Ln Amount of BLT fund; Ln_BLTRp & & -0.000 \\
\hline Smoker status $(\text { smoker }=1)^{21}$ & $10.655^{* * *}$ & $10.694 * * *$ \\
\hline Age of household head (years) & $-0.005 * * *$ & $-0.005 * * *$ \\
\hline Sex of household head $(\operatorname{man}=1)$ & $-0.145 * * *$ & $-0.114 * * *$ \\
\hline Schooling of household head (years) & $0.018 * * *$ & $0.019 * * *$ \\
\hline Number of household members & $0.025 * * *$ & $0.0261 * * *$ \\
\hline Number of males in household & $0.106^{* * *}$ & $0.098 * * *$ \\
\hline Number of children in household & $-0.0158 *$ & $-0.016^{*}$ \\
\hline \multicolumn{3}{|l|}{ Characteristic of Residence } \\
\hline Live in rural area $($ yes $=1$ ) & $-0.077 * * *$ & $-0.075^{* * *}$ \\
\hline Distance to sub-district capital & $-0.003 * *$ & $-0.003 * *$ \\
\hline Distance to district capital & 0.000 & $0.000 *$ \\
\hline Distance to market & $0.006 * *$ & $0.005^{*}$ \\
\hline Availability of electricity (yes $=1$ ) & $0.154 *$ & $0.179^{* *}$ \\
\hline Availability of water pump (yes $=1$ ) & 0.019 & 0.035 \\
\hline Availability of market (yes $=1$ ) & -0.021 & -0.017 \\
\hline Availability of station (yes $=1$ ) & -0.002 & 0.003 \\
\hline Kind of road (paved road, asphalt $=1$ ) & 0.055 & 0.033 \\
\hline Availability of finance institution (yes $=1$ ) & -0.002 & 0.007 \\
\hline \multicolumn{3}{|l|}{ Intercept } \\
\hline & $-0,180^{*}$ & $-0,252 * *$ \\
\hline $\mathrm{R}^{2}$ & 97.87 & 97.90 \\
\hline $\mathrm{N}$ & 17,473 & 15,374 \\
\hline
\end{tabular}

Source: author's calculation, 2016

Fixed Effect (2): fixed effect at village level

$* * *$ : Significant at $\alpha=1 \%$; **: significant at $\alpha=5 \%$; *: significant at $\alpha=10 \%$

This study showed that the BLT program could lessen the cigarette consumption of households. The permanent income hypothesis gives an intuition that the money received from the BLT was used for investments. However, because of the small amount given by the BLT fund, it could not generate a high enough return to raise their consumption. That first investment still needs more funding, therefore the

20 In_real consumption, base: 2000. The real value was calculated based on the GDP deflator from the statistics of the World Bank's website. The variable of cigarette consumption and total amount of BLT fund were transformed to a log natural (Ln).

21 Smoker status means that there was at least one smoker in the household. households should reduce their consumption to free more money for investment. For example, the household could use the BLT funds to buy a television, so their electricity bill will increase. Another example, a household uses the BLT fund as a down-payment to buy a motorcycle to get a new job as an 'ojek'22 or to support their existing job. This will increase their costs for fuel and also they must meet the installment payments, although there is now an additional income, but it is still not enough to raise their consumption of cigarettes.

\footnotetext{
${ }^{22}$ Ojek is a motorcycle taxi.
} 
Of the examples were the BLT funding was used as down-payments for purchasing land, houses, etc. then they had to reduce their future consumption to pay the installments due on the land or house. If the BLT funds were used to buy rice seeds, in the subsequent months they had to buy fertilizer, etc. for the continuity of their investment. Similarly, if the funds were used for rotated saving, that is common among the public, then in the following months the recipient households must reduce their consumption to continue paying into the saving fund. The households need to reduce their consumption to meet that cost. As an alternative they reduce their cigarette consumption, as it is common knowledge that cigarettes have a negative effect on health, and cigarettes are not generally considered to be a major or necessary consumption item by the household.

Table 1 shows that, on average, the amount of BLT funds received by each household in the last year was Rp777,500. It makes sense if the funds are used for investments, $\operatorname{arisan}^{23}$ or the purchase of household appliances, and so on. These phenomena can be proved by identifying the impact of the BLT program on assets or investments owned by the household through further research. The results of this study are similar to Yamauchi (2005) in the case of the Inpres Desa Tertinggal (IDT) grant program in Indonesia in 1995, which provided a maximum grant of approximately Rp400,000. Yamauchi (2005) concluded that the funds from the IDT program were used by the public for investment, and proved capable of encouraging an increase in the working hours of male-children. Although there was a difference in real terms between the value of the IDT and the BLT funding, the value of the BLT funds received on average per household was approximately Rp777,500. This is considered to be a sufficient amount to be invested by a poor household at that time.

\footnotetext{
${ }^{23}$ Arisan is translated as rotated saving. Rotated savings are held by a group of people who collect money on a regular basis. Once the money is collected, one of the members of the group will come out as the winner. The determination of the winner is usually done with a draw. Rotated savings operate outside the formal economy as another way to save money.
}

According to the finding of Yamauchi (2005), it makes sense if the BLT funds are used for savings or investment. Moreover, most of the people in Indonesia are educated about saving diligently (investments) from an early age, which appears in the motto 'Saving is the base of the rich' ${ }^{24}$. In addition to the benefits gained from the transfer program, Das et al. (2005) revealed that a similar transfer system in Mexico was able to increase the investments by the communities receiving it.

The analysis showed that the BLT has a positive effect in influencing the consumption of cigarettes. It means that the BLT fund can lessen cigarette consumption. According to the permanent income hypothesis, the BLT can be categorized as a transitory income. Equation (5) showed that a transitory income could increase the savings of the household. Because it decreased the consumption of cigarettes, and the hypothesis showed that the savings could increase, it indicates that the recipients of the BLT used the BLT funds for their investments. They reduced their cigarette consumption as a consequence of their investments, because cigarettes are not a major need for household. And, it was because the recipients of the BLT needed to maintain the continuity of their investments, and the BLT funds, which were used for the initial investment, were not sufficient to be used for a long-term investment.

The results of this study can also explain the study by Rasyid (2013). He revealed that people who normally provide transfers to their poorer neighbors and/or relatives reduced or eliminated their transfers to them. This was because they considered that the poor had received aid from the government. So because of the BLT program, the income of these poor households that previously relied on those transfers, would be the same before and after the program because there was a reduction in the private transfers. As a result, the BLT fund was not enough for the poor to maintain their consumption related to the increase in the price

\footnotetext{
24 'Menabung pangkal kaya' is a motto for Indonesians and is inculcated at an early age. 'Menabung pangkal kaya' translates into 'saving is the base of the rich'.
} 
of fuel, which had the effect of increasing the price of most other goods ${ }^{25}$. Therefore, the poor households (the recipients of the BLT) decreased their consumption of cigarettes. Another reason is because cigarettes are not a basic or staple need. Thus further identification of the impact of the BLT program to asset and/or investment could be conducted to examine the arguments.

Further research that can also be done is to analyze the effects of the BLT on savings/ investments, assets and rotated savings. It can also analyze the impact of the BLT on the increase in working hours. The issue is that it is possible that the BLT funds were used for investments which can then increase the working hours, as a result of the investment. Yamauchi (2005) has revealed that the invested funds caused an increase in the working hours. Investment will provide the creation of new jobs or expanded employment opportunities, which lead to an increase in working hours. The impact of investments made from the BLT funds can increase the consumption of the recipient households, but it can happen in the long run. Further research can be conducted to examine this.

\section{CONCLUSION}

Giving the BLT funding to poor households, as compensation for the increase in fuel prices was a wise policy. The study proved that the BLT might have positive impacts i.e. reducing the expenditure on cigarettes by households that received the BLT. The results of this study indicate that poor households, as recipients of the BLT, used the funds for investments, rotated savings, and other forms of saving; following the permanent income hypothesis. The investment of the BLT funds had encouraged people to reduce their consumption expenditure and they decreased their cigarette consumption, as it was not an important or majority need in their households.

There are some reasons that can explain this phenomena: 1) The BLT fund was used for an investment; so that the household recipients of

\footnotetext{
25 The implementation of the BLT program coincided with the policy of oil price increases
}

the BLT reduced what they considered to be the non-essential i.e. consumption of cigarettes; 2) in maintaining and improving their investment/ saving, the household lessens their future cigarette consumption; 3) when the BLT pro gram was implemented, people tended to reduce or abolish their transfers to the poor households that received the BLT. Therefore the income of the poor households received from private transfers would be almost the same, or may even be lower. Thus the recipients of the BLT changed their consumption patterns and reduced their cigarette consumption. Further identification of the impact of the BLT program on assets and/or investments could be conducted to examine those arguments.

This study concluded that the BLT program had a positive impact on society i.e. the decreasing of cigarette consumption. It is because cigarettes have more disadvantages than benefits. Giving the BLT funds every three months or more to the BLT recipient households made the BLT funding they received sufficient to make a 'small investment'. Therefore, the BLT recipient households decreased their cigarette consumption as the consequence of needing to maintain the continuity of their investment. They choose to decrease the cigarette consumption because it is not the primary need of the household.

\section{REFERENCES}

Abidin, S.Z. (2012). "Bantuan Langsung Tunai dan Dampaknya [Unconditional Cash Transfers and Their Impact]". http://news.detik.com/kolom/d1876334/bantuan-langsung-tunai-dandampaknya. Accessed 2 July 2014.

Andrews, R. L. \& Franke, G. R. (1991). "The Determinants of Cigarette Consumption: A Meta-Analysis". Journal of Public Policy \& Marketing 10(1): 81-100.

Cameron, L., \& Shah, M. (2012). Can Mistargeting Destroy Social Capital and Stimulate Crime?: Evidence from Cash Transfer Program in Indonesia. Victoria: Monash University.

Cox, D., Hansen, B. E., \& Jimenez, E. (2004). "How Responsive Are Private Transfers to 
Income? Evidence from a Laissez Faire Economy". Journal of Public Economics, 2193-2219.

Das, J., Toan Do, Q., \& Ozler, B. (2005). "Reassessing Conditional Cash Transfer Programs". The World Bank Research Observer 20(1): 57-80.

Eshghi, A. \& Lesch, W. (1993). "Demographic and Life Style Determinants of Household Consumption Patterns". Journal of Marketing Theory and Practice 2(1): 80102.

Friedman, Milton. (1957). A Theory of the Consumption Function. Princeton, N.J: Princeton University Press.

Gallus, S., A. Schiaffino, C.La Vecchia, J. Townsend, \& E. Fernandes (2006). "Price and Cigarette Consumption in Europe". Tobacco Control 15(2): 114-119.

Gertler, P., \& Molyneaux, J. W. (1994). "How Economic Development and Family Planning Programs Combined to Reduce Indonesian Fertility". Demography, 31(1), 33-63.

Heckman, J. J., \& Robb, R. (1985). “Alternative Methods for Evaluating the Impact of Interventions: An Overview". Journal of Econometrics, 30, 239-267.

Hossain, N., Brook, S., Garbarino, S., Notosusanto, S., Noor, I.R., \& Seda, F. (2012). Qualitative Assessment: The Social Impacts of Cash Transfer Programmes in Indonesia. Tim Nasional Percepatan Penanggulangan Kemiskinan (TNP2K).

Isdijoso, W., A. Suryahadi, \& Akhmadi. (2016). "Penetapan Kriteria dan Variabel Pendataan Penduduk Miskin yang Komprehensif dalam Rangka Perlindungan Penduduk Miskin di Kabupaten/Kota [Establishment of Comprehensive Criteria and Variables on Poor People for their Protection in Districts/Cities]". The SMERU Research Institute.

Khandker, S. R., Koolwal, G. B., \& Samad, H. A. (2010). Handbook on Impact Evaluation, Quantitative Methods and Practices. Washington DC: The World Bank.

Medan, R. (2010). "BPS Harus Ubah Kriteria Masyarakat Miskin [BPS Must Change the Criteria for Being Designated Poor]". http://www.tribunnews.com/tribunners/2010 /10/25/bps-harus-ubah-kriteria-masyarakatmiskin. Accessed 2 July 2014.

Miles, D. (1997). "A Household Level Study of the Determinants of Incomes and Consumption". The Economic Journal 107(440): 125.

Park, C. (2003). "Inter household Transfers between Relatives in Indonesia: Determinants and Motives". Economic Development and Cultural Change 51(4): 929-945.

Pitt, M. M., Khandker, S., McKernan, S., \& Latif, M. A. (1999). "Credit Programs for the Poor and Reproductive Behavior in Low Income Countries: Are the Reported Causal Relationships the Result of Heterogeneity Bias?" Demography, 36(1): 1-21.

Rasyid, M. (2013). "Crowding-out Effect of Cash Transfer Programs on Inter-household Transfers: Evidence from Indonesian Family". Journal of Economics and Sustainable Development 4(2): 47-53.

Rawlings L.B., \& Rubio, G.M. (2005). "Evaluating the Impact of Conditional Cash Transfer Programs". The World Bank Research Observer 20(1): 29-55.

Ressler P. (2008). The Social Impact of Cash Transfers. Regional Network on AIDS, Livelihoods and Food Security International Food Policy Research Institute.

Romer, D. (2012). Advance Macroeconomics. $4^{\text {th }}$ edition. McGraw-Hill. New York.

Sapa.or.id. (2014). "Program Bantuan Langsung Tunai [Direct Cash Assistance Program]". http://www.sapa.or.id/berita1/99-

lainnya/642-program-bantuan-langsungtunai.html. Accessed 2 July 2014.

Sharma, A., \& Lal, D. (2009). "Private Household Transfers and Poverty Alleviation in Rural India: 1998-1999". The Journal of Applied Economic Research, 3 (2), 97-112.

Shefrin, H. M. \& R.H. Thaler. (1988). "The Behavioral Life-Cycle Hypothesis". Economic Inquiry 26(4): 609-643.

Soares, Fabio V; Ribas, R \& Osorio, R. (2010). "Evaluating the Impact of Brazil's Bolsa Familia: Cash Transfer Programs in Comparative Perspective". Latin American Research Review 45(2): 173-190.

Suaramerdeka.com. (2014). 'Subsidi BBM, Antara Kebijakan dan Politis [Fuel Subsidy, Between Policies and Politics]'. 
http://www.suaramerdeka.com/v1/index.php $/ \mathrm{read} /$ cetak/2014/04/21/259340/SubsidiBBM-Antara-Kebijakan-dan-Politis. Accessed 2 July 2014.

Witoelar, F., Strauss, J. \& Sikoki, B. (2009). "Socioeconomic Success and Health in Later Life: evidence from the Indonesia family life survey". RAND Labor and Population Working Paper Series.
Wooldridge, J. M. (2003). Introductory Econometrics: A Modern Approach, Second Edition.

Yamauchi, Chikako (2005). "Evaluating Poverty Alleviation through Microcredit: Methodological and Empirical Evidence from Indonesia", Job Market Paper, Department of Economics University of California.

Notice: The Journal of Indonesian Economy and Business and its Board of Editors are not responsible for any errors or flaws found in this article. The authors take full responsibility for their work. 